\title{
Linear Frictional Properties of a Barbed Suture in the Tendon Tissue
}

\author{
Çapalı Bir Dikişin Tendon Dokusunda Doğrusal Tutunma Özellikleri
}

Halil Can Gemalmaz

Acıbadem Mehmet Ali Aydınlar University School of Medicine, Kerem Aydinlar Kampusu, Istanbul, Turkey

\section{ABSTRACT}

Objective: The barbed suture has been around for some time with some important theoretical advantages for tendon repairs such as resistance to suture slippage and knotless application. However, these theoretical advantages are not yet proven to be practically important. The literature on the barbed suture for tendon repair has a focus on in-vivo or ex-vivo preclinical investigations of established tenorrhaphy methods. Current literature is poor in knowledge on its fundamental properties thus basic research. Our study attracts attention on the lack of basic research on barbed suture for tendon repair and investigates a barbed suture's linear frictional performance in the tendon.

Methods: Thirty-two fresh frozen porcine forefoot digital flexor tendons were separated into four groups of eight tendons. In group 1 a barbed suture was introduced to the tendons $1 \mathrm{~cm}$ proximal to the distal cut-end and was advanced through the core of the tendon tissue leaving the distal cut-end at the core. In group 2 the suture was introduced in the same way purchasing $2 \mathrm{~cm}$ of tendon tissue, in group 3 and 4 the suture purchase length was 3 and $4 \mathrm{~cm}$ respectively. Ultimate tensile strength generated by anchorage of the barbs of the suture in the tendon tissue was assessed with a mechanical testing machine and the results were statistically compared between groups.

Results: Mean ultimate tensile strength was found to be $5.4 \mathrm{~N}$ for group $1,7.45 \mathrm{~N}$ in group 2, 4.87N in group 3 and $5.76 \mathrm{~N}$ for group 4 . Intergroup comparison was made with a data set corrected for suture purchase length which was obtained by dividing each sample's ultimate tensile value by the distance of suture purchase length accordingly. Statistical analysis with corrected data set revealed that group 1 versus 2 showed no difference whereas comparison of group 1 vs 3 and group 1 vs 4 showed a significant difference.

Discussion: Our results showed that the frictional forces generated by the barbed suture were directly proportional to the suture purchase length only to some extent. Statistical analysis confirmed the direct linear relation between pullout strength and suture purchase length up to 2 centimeters of suture purchase. Pullout strength in samples with 3 and 4 centimeters of suture purchase showed deterioration.

Conclusion: The tissue grasping strength of the barbed suture we tested in our study is not directly proportional to the suture purchase length. More basic research on barbed suture for tendon repair is needed to better understand how its theoretical advantages can be appreciated practically. Suture producing companies should investigate and produce barbed sutures specially tailored for tendon repair.

Key Words: Barbed suture, suture/tissue pullout test, tendon repair

\section{ÖZET}

Amaç: Tendon onarımı senaryolarında çapalı dikişler dokudan dikiş sıyrılmasına karşı yapısal direnç göstermeleri ve düğüm bağlanmaksızın kullanım sağlamalar nedeniyle konvansiyonel dikişlere göre bazı teorik avantajlar sunmaktadır. Güncel literatür çapalı dikişlerle konvansiyonel tendon tamir teknikler kullanılarak yapılan in-vivo ve ex-vivo hayvan araştırmalarına odaklanmaktadır. Çapalı dikişlerin tendonda kullanımı ile ilgili temel özelliklerinin saptanmasına yönelik temel araştırmalar ise mevcut değildir. Araştırmamız bu eksikliğe vurgu yaparak çapalı bir dikişin tendon dokusunda tutunma gücünü doğrusal çekme testi ile araştırmaktadır.

Yöntemler: Otuz iki taze donmuş domuz ön ayak dijital tendonu sekizerli dört gruba ayrıldı. Birinci gruptaki örneklere çapalı dikiş tendonun içinde 1 santimetre mesafe kat edecek şekilde uygulandı. İkinci, üçüncü ve dördüncü gruplardak örneklere çapalı dikişler tendonun içinde sırasıyla 2, 3 ve 4 santimetre mesafe kat edecek şekilde uygulandı. Çapalı dikişlerin tendon dokusu içinde tutunma güçleri mekanik test cihazı ve doğrusal maksimum çekme dayanım testi kullanılarak ölçüldü. Gruplar arasındaki fark istatistiksel olarak değerlendirildi.

Bulgular: Ortalama maksimum çekme dayanımı birinci grupta $5.4 \mathrm{~N}$, ikinci grupta $7.45 \mathrm{~N}$, üçüncü grupta $4.87 \mathrm{~N}$ ve dördüncü grupta $5.76 \mathrm{~N}$ olarak bulundu. Gruplar arası karşılaştırma yapmak için örneklerin maksimum çekme dayanım değerleri çapalı dikişlerin tendon içinde kat ettikleri mesafeye bölünerek elde edilen düzeltilmiş değerler kullanıldı. Düzeltilmiş değerlerle yapılan istatiksel analiz sonucunda 1 ve 2.nci gruplar arasında fark bulunmazken, 1-3 ve 1-4 gruplar arasında fark bulundu.

Sonuç: Sonuçlarımız deneyde kullandığımız çapalı dikişin tendon içinde kat ettiği mesafe ile tendon dokusunda ürettiği tutunma gücünün doğrusal orantıl olmadığını ortaya koymaktadır. Çapalı dikişlerin tendon onarımında rollerinin daha iyi anlaşılabilmesi için daha dazla temel araştırmaya ihtiyaç vardır.

Anahtar Sözcükler: Çapalı dikiş, sütür/doku pullout testi, tendon onarımı

Geliş Tarihi: 11.06 .2018

Kabul Tarihi: 23.09 .20

Address for Correspondence / Yazışma Adresi: Halil Can Gemalmaz, MD Acıbadem University, School of Medicine, Kerem Aydinlar Kampusu Kayisdagi Cad. 32 Atasehir, Istanbul, Turkey E-mail: cgemalmaz@gmail.com

(CTelif Hakkı 2019 Gazi Üniversitesi Tıp Fakültesi - Makale metnine http://medicaljournal.gazi.edu.tr/ web adresinden ulaşılabilir.

(C) Copyright 2019 by Gazi University Medical Faculty - Available on-line at web site http://medicaljournal.gazi.edu.tr/

doi:http://dx.doi.org/10.12996/gmj.2019.40 


\section{INTRODUCTION}

The ideal tendon suture repair should be strong enough to allow early mobilization, easily performed, minimize injury to tendon vasculature, and minimize the bulk at the repair site while providing the smoothest possible gliding surface (1-3). It is well known that repairing the tendons with a greater number of suture strands crossing the repair site results in higher tensile strengths $(2,4-6)$. However, the increased number of strands, bulky knots and complex suture trajectories are known to increase gliding friction, cause excessive inflammation and cause circulatory compromise, which are responsible for impaired outcomes in tendon repair (1-3,7-11). Therefore, the suture technique used to approximate a severed tendon is crucial for achieving a better outcome, since it is well known that poor handling of the tendon tissue during surgery leads to poor outcomes (12).

Barbed sutures do not have to rely on complex trajectories, multiple loops or even knots to provide tissue grasp and friction. Instead, a barbed suture relies on homogenous tissue grasp and friction throughout the monofilament suture material $(13,14)$. This core characteristic of the barbed suture comes from the circumferentially and evenly distributed spikes or anchors throughout the filament. These spikes generate homogenous and steady friction against slippage throughout suture trajectory in the opposite direction of suture introduction $(14,15)$. Theoretically, this advantage may lead to a reduced need to obtain complex trajectories with acute angles, multiple loops or tying knots which are proven to be mechanical stress risers and possible reasons for failed tendon repair $(12,13)$.

Literature provides very little information about fundamental properties of an ideal barbed suture for tendon repair (13-15). Yet, most of the available literature on barbed sutures for tendon repair has a focus on comparison of its effectiveness against standard sutures with standard tenorrhaphy techniques in the ex-vivo or in-vivo preclinical setting $(6,12,16-22)$. We find this very awkward while the barbed sutures are described by both the manufacturers and the US Food and Drug Administration as a wound closure device (23). This indicates that the current literature is deficient in basic science regarding the barbed suture for tendon repair.

The barbed suture's linear frictional property in the tendon tissue is such a topic that needs to be investigated in order to contribute for a better practical understanding which may help to design and propose innovative tenorrhaphy techniques. We planned this study to investigate a specific barbed suture's linear fictional performance in tendon tissue with the hypothesis; that the amount of frictional tension a barbed suture generates is proportional to the distance it spans through the tendon tissue.

\section{MATERIALS AND METHODS}

The surgical and biomechanical test method

All ex-vivo specimen used in the study were obtained from animals which were euthanized for endoscopic education purposes in our institution, thus no ethics committee approval was obtained. Thirty-two porcine forefoot digital flexor tendons were surgically extracted from freshly euthanized animals and were fresh frozen in an industrial fridge at -21 centigrade for later use. After thawing of the specimen, they were divided into four groups of eight tendons. In group 1 a V-Loc 180 Absorbable Wound Closure Device $(37 \mathrm{~mm} 1 / 2$ circle round taper needle, 0 imperial $/ 3.5$ metric) was introduced to the tendon $1 \mathrm{~cm}$ proximal to the distal cut-end and was advanced through the core of the tendon tissue leaving the distal cut-end at the core. In group 2 the suture was introduced in the same manner purchasing $2 \mathrm{~cm}$ of tendon tissue, in group 3 and 4 the suture purchase length was 3 and $4 \mathrm{~cm}$ respectively (Figure 1 and 2). The tendon was stabilized at both ends by an assistant to facilitate suture passage through the desired core trajectory. In groups 3 and 4 marked difficulties were encountered while trying to advance rather large $1 / 2$ circular needle through a rather small diameter flexor tendon. A $10 \mathrm{kN}$ Shimadzu Autograph AGS-J model universal testing machine (Shimadzu Corp., Kyoto, Japan) was used to assess ultimate tensile strength that the suture-tendon interface generates through friction caused by anchorage of the barbs of the suture in the tendon tissue (Figure 3). The both ends of the samples were mounted directly to the clamps of the mechanical testing device making sure that the samples were parallel to the pull direction of the device. The mechanical testing device was preloaded with 1 newton of force before the pull test and the testing was stopped manually once visual suture slippage from tendon was confirmed.

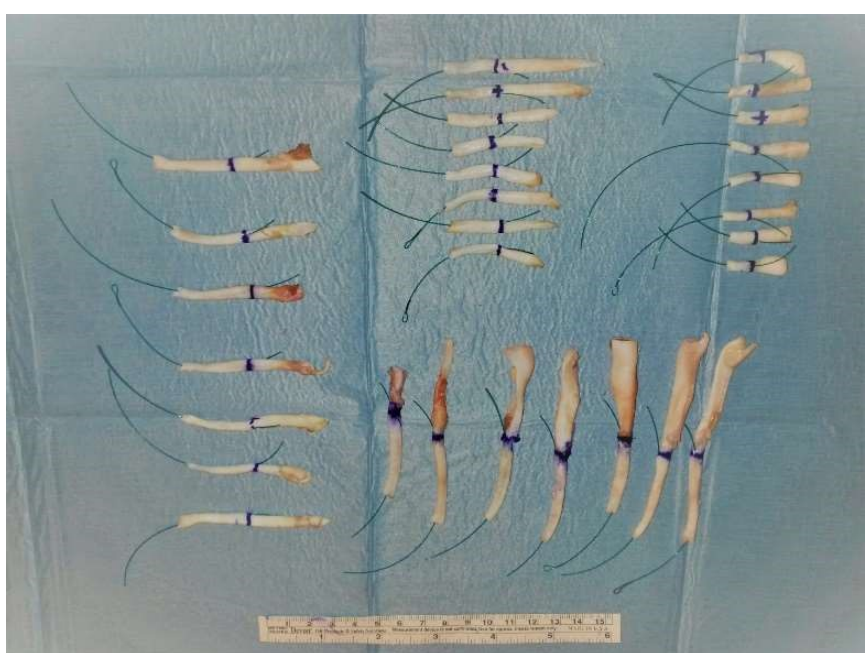

Figure 1: A photo of the specimens before ultimate tensile strength test.

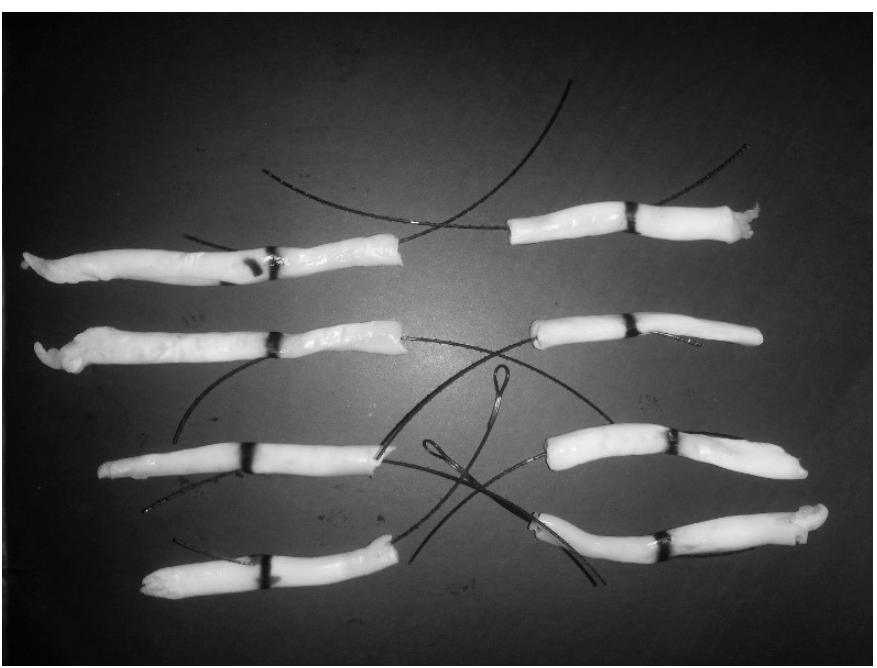

Figure 2: A close-up photo of the specimens from group 2 depicting some detail of the barbed structure of the suture.

Table 1: Table summarizing ultimate tensile strength of each sample, mean and mean values corrected by suture purchase length by groups.

\begin{tabular}{lllll}
\hline Sample & Group 1 & Group 2 & Group 3 & Group 4 \\
\hline 1 & 6.50 & 8.24 & 9.87 & 5.93 \\
2 & 5.15 & 8.46 & 2.72 & 8.72 \\
3 & 4.43 & 7.18 & 1.93 & 9.48 \\
4 & 6.75 & 5.90 & 6.27 & 2.13 \\
5 & 6.16 & 11.07 & 5.96 & 3.40 \\
6 & 4.95 & 6.56 & 2.81 & 7.33 \\
7 & 3.79 & 5.60 & 3.83 & 2.75 \\
8 & 5.54 & 6.65 & 5.63 & 6.42 \\
Mean & 5.40 & 7.45 & 4.87 & 5.76 \\
Mean /suture purchase & 5.40 & 3.72 & 1.62 & 1.44 \\
\hline length & & & & \\
\hline
\end{tabular}




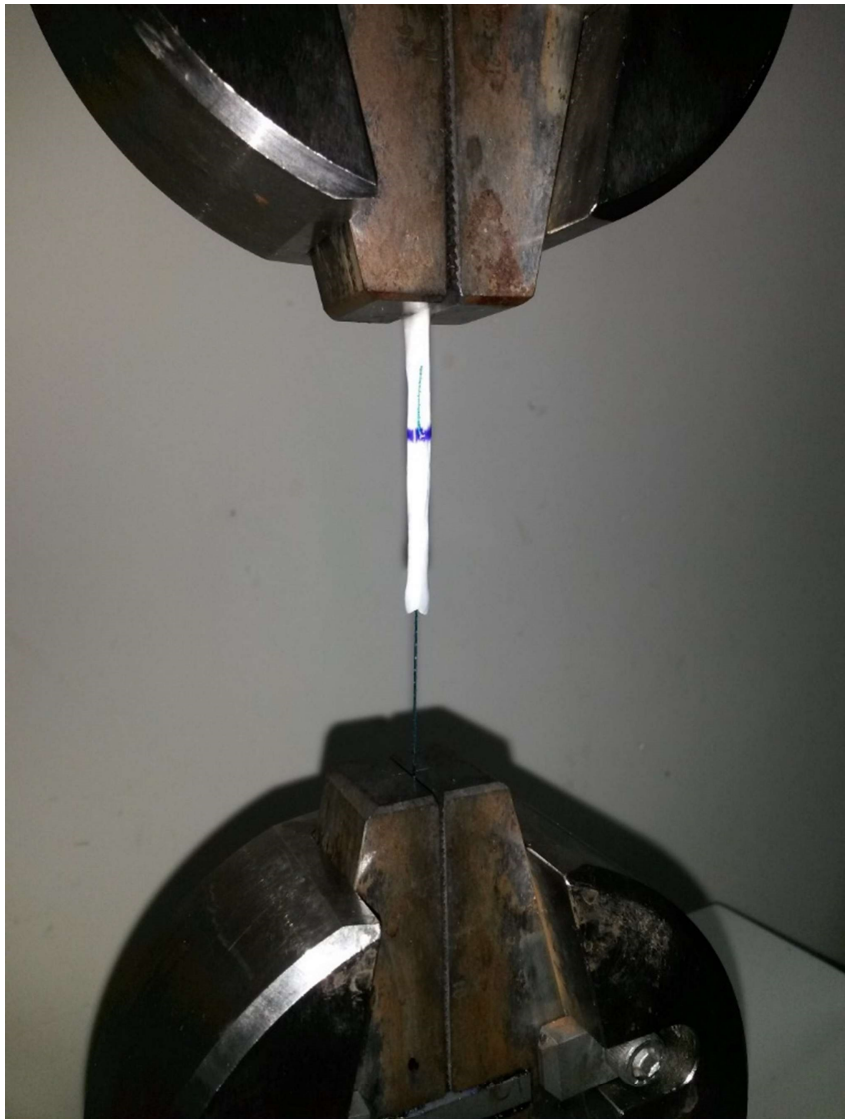

Figure 3: A photo showing a specimen from group 3 while being tested for ultimate tensile strength.

\section{Statistical analysis}

The correlation between suture purchase length and ultimate tensile strength was tested with Spearman's correlation test. Since a directly positive relation between suture purchase length and ultimate tensile strength is anticipated a statistical model to test this is implemented by calculating a "corrected comparison value" for each sample. The "corrected comparison value" for each sample was found by dividing ultimate tensile strength values by suture purchase length of each sample. In other words, values in group 1 were divided by 1 , values in group 2 were divided by 2 and values in the 3rd and 4th groups were divided by 3 and 4 consecutively. These "corrected comparison values" were than used to assess any significant difference between groups with independent samples Kruskal Wallis test. SPSS 21.0 for Windows (Release 21.0, SPSS Inc, Chicago, IL, USA) computer software was used for statistical analysis.

\section{RESULTS}

All specimen in all groups failed by stripping of barbs from the tendon tissue, no failure due to suture breakage or tendon and suture stripping from the mount was encountered. Mean value of ultimate tensile strength was found to be $5.4 \mathrm{~N}$ for group 1, 7.45N in group 2, 4.87N in group 3 and $5.76 \mathrm{~N}$ for group 4 (Table 1). The Spearman correlation test showed no significant relation between suture purchase length and ultimate tensile strength ( $p=0.84$, two-tailed). Since this was an unexpected result further analysis was performed to reveal inter group differences. The calculated comparison values were used to assess any significant difference between groups with independent samples Kruskal Wallis test. Kruskal Wallis test revealed significant difference $(H=24.23,3$ d.f., $\mathrm{P}=0.02 \times 10^{-3}$ ) Post-hoc analysis with Bonferroni correction revealed that groups 1 vs 2 showed no difference whereas comparison of group 1 vs 3 and group 1 vs 4 showed significant difference. Table 2 summarizes these post-hoc analysis results.
Table 2: Table summarizing post-hoc intergroup comparisons with adjusted significance for Bonferroni correction

\begin{tabular}{lll}
\hline $\begin{array}{l}\text { Intergroup } \\
\text { comparison }\end{array}$ & Test Statistic & $\begin{array}{l}\text { Adjusted } \\
\text { significance }\end{array}$ \\
\hline $1 \mathrm{vs2}$ & 6.87 & 0.85 \\
$1 \mathrm{vs3}$ & 18.37 & $\mathbf{0 . 0 0 1}$ \\
$1 \mathrm{vs4}$ & 19.75 & $<\mathbf{0 . 0 0 5}$ \\
$2 \mathrm{vs3}$ & 11.50 & 0.08 \\
$2 \mathrm{vs4}$ & 12.87 & $\mathbf{0 . 0 3 6}$ \\
$3 \mathrm{vs4}$ & 1.37 & 1.00 \\
\hline
\end{tabular}

\section{DISCUSSION}

To our knowledge, our study is the first study to assess the linear frictional performance of a barbed suture in the tendon tissue. The known and established parameters for a barbed suture which are related to linear frictional performance are mainly related to issues regarding filament. Previous research has shown that diameter of the filament, barb density, barb geometry and barb depth are the main factors that seem to affect the frictional resistance of a barbed suture in the tissue $(14,15)$.

In this biomechanical study there were four groups and in group 1 the length of the tendon tissue spanned by the suture was $1 \mathrm{~cm}$, in group 2 it was $2 \mathrm{~cm}$ and in groups 3 and 4 there were consequently 3 and 4 centimeters. In other words, the number of barbs in the tissue was the differentiating factor between the groups which is presumably proportional to the length of the suture in the tendon tissue since the barbs in the suture are homogeneously distributed. Samples in group 2 which had two times the length of suture material in tendon when compared to group 1 showed a directly proportional increase in ultimate tensile strength. However, while we were expecting the same direct proportional increase in groups 3 and 4 analysis did not prove so. In fact, our results showed that the ultimate tensile strength of the barbed suture deteriorated in these groups indicating that there may be other variables contributing to the frictional performance of the barbed suture in tendon tissue. We believe this issue of awkward frictional performance of the barbed suture might be related to the needle of the suture. As mentioned in the materials and methods section of our manuscript we encountered difficulty passing the $37 \mathrm{~mm} 1 / 2$ circular, rather large needle through the core of the tendon in groups 3 and 4 where consecutively 3 and $4 \mathrm{~cm}$ of tendon tissue was spanned by the suture. We believe this rough procedure might have detrimental effects on tendon tissue by dilating the suture trajectory and breaking structure of tendon fibrils. However, this has yet to be proven by new investigations. Nevertheless, it is clear that the needle of the suture was not ideal for our study design. Currently, the barbed sutures are only being produced and labeled as wound closure devices so ideal needle options for tendon repair are not the priority list of barbed suture manufacturing companies.

As afore mentioned in the introduction section we believe that unique tissue grasping properties of the barbed suture separates it from the classical suture material thus, the tendon repair technique should also differ from the classical tendon repair techniques. To our knowledge, there is only one study which has investigated the barbed suture for possible new tendon repair techniques and it is most probably the oldest one by McKenzie in the year 1967 (13). He has described the suture as "An experimental suture for certain compact (low caliber) tendons capable of giving neat and relatively atraumatic approximation" and he also noted that it provided comparable results to Bunnel "buried core" technique with an in-vivo animal model. In his work, he described a couple of possible repair configurations for flexor digital tendon repair. To our knowledge, these are the first described surgical methods that take advantage of the barbed suture's linear frictional properties by eliminating complex trajectory, multiple loops and knots. These tendon suture configurations were generally two separate filaments passing through the severed tendon in a reverse parabolic orientation. 
No knots or suture tying was described but some configurations showed anchorage of suture over the skin in a classical pull-out fashion. Unfortunately, after his study research on the barbed suture for tendon repair was scaled down for a very long time. This might be a result of the inefficacy of technology at his time for manufacturing quality and economic barbed sutures. After many years of being lost to surgical procedures, barbed sutures made a comeback in the 21st century with some product diversity and economic availability. As a result, some recent data has accumulated for the barbed suture's role in tendon repair scenarios.

Most of the available literature on the barbed suture for tendon repair cases has a focus on comparison of its effectiveness against standard sutures with standard tenorrhaphy techniques. We believe that modern tenorrhaphy techniques have excelled for regular sutures through years of basic and clinical research. Therefore, the proven tenorrhaphy methods of today are actually tailored to the properties of regular sutures through many years of practice and research. As a result, comparing barbed sutures to standard sutures employing established tenorrhaphy techniques may not be the best way of discovering their potential for tendon repair. Yet, recently the research community has mainly focused on just doing that $(12,16-22)$. Since there is little basic science behind these clinical studies, we find them impractical for defining the role of barbed suture for tendon repair. On the other hand, few studies have attracted attention on basic properties of the barbed suture, suggesting that the ideal barb geometry may not be the same for all surgical procedures and tissue types $(14,15,24)$. Among these, a biomechanical study by Ingle and King reported that due to tendon tissue's higher modulus of elasticity compared to skin, any barb to penetrate tendon tissue needs to be more rigid. Thus, they recommended a barbed suture to have barbs cut at an angle of $150^{\circ}$ at a depth of $0.18 \mathrm{~mm}$ for tendon repair and a cut angle of $170^{\circ}$ at a depth of $0.18 \mathrm{~mm}$ for skin tissue $(14,24)$. Nevertheless, we believe that linear frictional characteristics of different barbed sutures with different needles, filament diameters, barb geometry and barb density should be first investigated and understood to find itself a place in new tendon repair procedures.

\section{CONCLUSION}

The tissue grasping strength of the barbed suture we tested in our study is not directly proportional to the suture purchase length. Further investigation is needed to explain this behavior and to confirm the theoretical advantages of the barbed suture for tendon repair scenarios. If this can be achieved, there is the possibility that the repair techniques of today may evolve or new techniques may be proposed to take better advantage of the barbed suture.

Furthermore, to our knowledge, no suture company has introduced any barbed suture which is specially tailored for tendon repair. Our study along with the previous studies on tendon repair with barbed sutures indicate that the barbed suture for tendon repair needs to be specially designed from needle to diameter of the filament and from barb density to barb geometry.

\section{Conflict of interest:}

The author declared that there is no conflict of interest.

\section{REFERENCES}

1. Momose $T$, Amadio PC, Zhao C, Zobitz ME, An KN. The effect of knot location, suture material, and suture size on the gliding resistance of flexor tendons. J Biomed Mater Res. 2000;53:806-11.

2. Wu YF, Tang JB. Recent developments in flexor tendon repair techniques and factors influencing strength of the tendon repair. J Hand Surg Eur Vol. 2014;39:6-19.

3. Tang JB, Amadio PC, Boyer MI, Savage R, Zhao C, Sandow M, et al. Current practice of primary flexor tendon repair: a global view. Hand Clin. 2013;29:179-89.
4. Aoki M, Kubota $\mathrm{H}$, Pruitt DL, Manske PR. Biomechanical and histologic characteristics of canine flexor tendon repair using early postoperative mobilization. J Hand Surg Am. 1997;22:107-14.

5. Osada D, Fujita S, Tamai K, Yamaguchi T, Iwamoto A, Saotome K. Flexor tendon repair in zone II with 6-strand techniques and early active mobilization. J Hand Surg Am. 2006;31:987-92.

6. Barrie KA, Tomak SL, Cholewicki J, Wolfe SW. The role of multiple strands and locking sutures on gap formation of flexor tendon repairs during cyclical loading. J Hand Surg Am. 2000;25:714-20.

7. Tang JB. New Developments Are Improving Flexor Tendon Repair. Plast Reconstr Surg. 2018;141:1427-37.

8. Wong YR, Loke AMK, Tay SC. The Effect of Suture Materials on the Biomechanical Performance of Different Flexor Tendon Repairs and the Concept of Construct Efficiency. J Hand Surg Asian Pac Vol. 2018;23:2437.

9. Tang JB. Recent evolutions in flexor tendon repairs and rehabilitation. J Hand Surg Eur Vol. 2018;43:469-73.

10. Zhao C, Amadio PC, Zobitz ME, An K-N. Gliding characteristics of tendon repair in canine flexor digitorum profundus tendons. J Orthop Res. 2001;19:580-6.

11. Uchiyama S, Amadio PC, Berglund L, An K-N. Analysis of the gliding pattern of the canine flexor digitorum profundus tendon through the $A 2$ pulley. J Biomech. 2008;41:1281-8.

12. Trocchia AM, Aho HN, Sobol G. A re-exploration of the use of barbed sutures in flexor tendon repairs. Orthopedics. 2009;32. doi:10.3928/01477447-20090818-12

13. McKenzie AR. An experimental multiple barbed suture for the long flexor tendons of the palm and fingers. Preliminary report. J Bone Joint Surg $\mathrm{Br}$. 1967;49:440-7.

14. Ingle NP, King MW. Optimizing the tissue anchoring performance of barbed sutures in skin and tendon tissues. J Biomech. 2010;43:302-9.

15. Ingle NP, King MW, Zikry MA. Finite element analysis of barbed sutures in skin and tendon tissues. J Biomech. 2010;43:879-86.

16. McClellan WT, Schessler MJ, Ruch DS, Levin LS, Goldner RD. A knotless flexor tendon repair technique using a bidirectional barbed suture: an ex vivo comparison of three methods. Plast Reconstr Surg. 2011;128:322e 327e.

17. Parikh PM, Davison SP, Higgins JP. Barbed suture tenorrhaphy: an ex vivo biomechanical analysis. Plast Reconstr Surg. 2009;124:1551-8.

18. Peltz TS, Haddad R, Scougall PJ, Gianoutsos MP, Bertollo N, Walsh WR Performance of a knotless four-strand flexor tendon repair with a unidirectional barbed suture device: a dynamic ex vivo comparison. J Hand Surg Eur Vol. 2014;39:30-9.

19. Joyce CW, Whately KE, Chan JC, Murphy M, O'Brien FJ, Carroll SM. Flexor tendon repair: a comparative study between a knotless barbed suture repair and a traditional four-strand monofilament suture repair. J Hand Surg Eur Vol. 2014;39:40-5.

20. Zeplin PH, Zahn RK, Meffert RH, Schmidt K. Biomechanical evaluation of flexor tendon repair using barbed suture material: a comparative ex vivo study. J Hand Surg Am. 2011;36:446-9.

21. Marrero-Amadeo IC, Chauhan A, Warden SJ, Merrell GA. Flexor tendon repair with a knotless barbed suture: a comparative biomechanical study. J Hand Surg Am. 2011;36:1204-8.

22. Lin TE, Lakhiani C, Lee MR, Saint-Cyr M, Sammer DM. Biomechanical analysis of knotless flexor tendon repair using large-diameter unidirection barbed suture. Hand . 2013;8:315-9.

23. Matarasso A, Ruff GL. The History of Barbed Sutures. Aesthet Surg J. 2013;33(3 Supplement):12S - 16S.

24. Sasaki GH, Komorowska-Timek ED, Bennett DC, Gabriel A. An objective comparison of holding, slippage, and pull-out tensions for eight suspension sutures in the malar fat pads of fresh-frozen human cadavers. Aesthet Surg J. 2008;28:387-96. 